\title{
A truly market-value weighted Commodity Index*
}

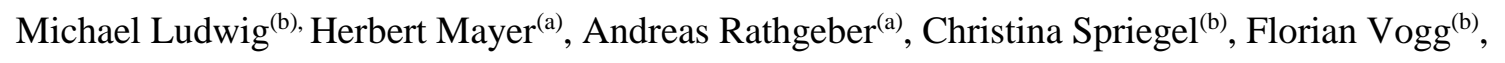

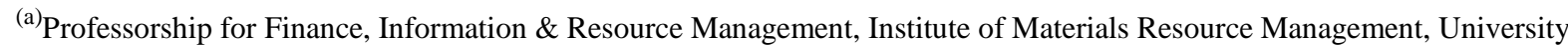
of Augsburg, 86135 Augsburg, Germany

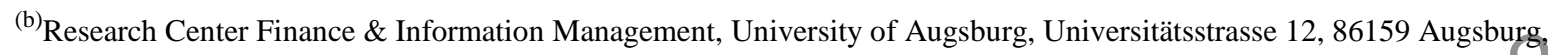
Germany

\begin{abstract}
Commodity indices play a central role in passive commodity investing However, a closer look at commodity indices reveals huge differences in construction and/weighting. For stock market indices on the other side, weighting is generally based on tha market căpitalization of an asset, according to the capital market theory. In contrast to this sound theoreticaland practicable basis for stocks, there is a serious deficiency in commodity indexation. Therefore, in line with the classical capital market theory we present a novel approach to determine the "total investable amount" of commodities, which is the essential requirement for market capitalization based commodity indexation. In addition, we show a comprehensive model application: aceording to the proposed index weighting, energy allocation is significantly undervalued in existing Index compositions, whereas metals and soft commodities are overvalued. Additionally, ourresults show that a market capitalization weighted commodity index offers very attractive risk-return-characteristics for investors, compared to existing commodity indices.
\end{abstract}

\section{Keywords}

Commodities, CAPM, indexation, portfolio management

JEL-Classification: G10, G11, G15

\footnotetext{
${ }^{*}$ Acknowledgements: This paper has already been presented-among others-at the following conferences: The 21 Annual Conference Multinational Finance Society (MFS), 2014, Prague, Czech Republic, the Annual Conference of the British Accounting \& Finance Association (BAFA), 2016, Bath, England 2015. Furthermore, the authors would like to thank Martin Wallmeier, Stefan Stöckl, Sheraz Ahmed as well as our anonymous referees for their valuable comments and suggestions.
} 


\section{Introduction}

The continuous increase of stock holdings in recent decades as well as the emerging relevance of equity trading have led to a strong demand for passive investment opportunities. Therefore, a large number of investment products (such as index funds, options, or futures) is based on indices, which form the basis of passive investment opportunities. Indices, however, are not solely used as a basis for financial products, but also fulfil an essential function as benchmarks for investment managers, for asset allocation as well as for performance measurement purposes (Amenc et al., 2006). Against this background, we experience an intense debate about the right form of indexation in the recent years. In particular, a theorybased standard such as the classical market-capitalization, which is still the dominating standard in equity indices, is sadly lacking concerning the increasingly important asset class of commodities. In fact, existing well-established commodity indices are based on completely different and rather arbitrary weightings and compilations. The main reason for this gap is the difficulty and complexity of approximating the overall market value of a commodity, which is the most essential requirement for market capitalization weighting. We take up this challenge and present a novel approach in determining the "total investable amount" of commodities in order to enable market capitalization based commodity indexation. We can further show that a commodity index based on market capitalization offers very attractive risk-return-characteristics to investors and outperforms existing indices. Therefore, this paper also provides important implications for practitioners, who might follow this approach and launch passive index investment products based on market capitalization.

According to the central conclusion of the classic capital market theory, holding the market portfolio ensures an investor maximum diversification and thereby is an efficient investment strategy. In line with theory, the majority of equity indices weight their constituents in reference to their respective market capitalization. Another important reason for the success of this weighting scheme is its relatively simple implementation with respect to operative trading, as price changes do not necessitate portfolio rebalancing (Amenc et al., 2006). Broby (2011), based on the work of Bailey (1992), states that an index should fulfil the following central requirements: utility for academia and practitioners; acceptability with the CAPM as an efficient portfolio; disciplined and objective construction from accessible information; representativeness; reflection of covariances of underlyings; factor exposure and finally investability. According to the author, these requirements are optimally met by indices using the market capitalization as its weighting criterion. The cap-weighted market portfolio thus ensures broadest possible diversification as well as low transaction costs at the same time. Broby (2007) in the same vein concludes that indices based on the theoretical CAPM framework are the best way to diversify unsystematic risk, leading to an unbiased relation between systematic risk and return. 
However, there is also some doubt about the validity of the model's underlying assumptions, starting with the studies of Haugen and Baker (1991) and Grinold (1992), which question the efficiency of traditional market capitalization weighting. But even before such criticism, several alternative index strategies had been proposed, which are briefly presented in the following.

Price-weighted indices determine the index value only by using the absolute price of each component and calculating the average. One of the oldest and most well-known representatives in this category is the Dow Jones Industrial Average (DJIA), composed of the 30 largest companies in the U.S. As the DJIA uses a rather historical weighing scheme, the central issue with this method is that assets with a low unit value weigh less in the index than assets with a high unit value. Another methodology, the socalled equal-weighting method, assigns the same weights to the entire set of index constituents (e.g. S\&P Equal Weight Index, Barron's 400). This form of weighting provides a contrarian strategy compared to the market-cap standard, as the weights always remain constant, which may be independent from the development of a company's capitalization. Hence, equal weighting is assigned as an option to remove potential inefficiencies of capitalization weighting. However, according to Southard and Bond (2003), the preference of equal weighting over market value weighting is not an optimal answer, as it does not imply a representative portfolio.

Moreover, the same authors present their idea named "intelligent indices" as an alternative solution. This concept belongs to the family of fundamental weighted indices and relies on the assumption known as the "noisy market hypothesis" - that the capitalization weighting standard might lead to an overinvestment in overvalued stocks and vice versa, when there is no price efficiency (Hsu 2006). Thus, advocates of fundamental indexing claim that the concept removes potential inefficiency of market value weighting. According to Arnott et al. (2005), weights are defined by fundamental factors such as firm size, book value, income, sales, gross dividend distributions, or number of employees - all representing observable proxies of the fair value of a company. Several empirical studies, like Basu and Forbes (2014), show that a fundamental-weighted index outperforms cap-weighted indices across different countries, even after accounting for transaction costs. Fisher et al. (2015) and other recent works do not completely reject classical cap-weighting, but rather adjust the cap-weights by fundamental information, leading to even less turnover and tracking error than pure fundamental weighting approaches. However, among others, Perold (2007) states that fundamental indexing is not more than a strategy of active security selection through investments in value stocks. Amenc et al. (2009) show that the outperformance of fundamental indexation disappears, when adjusting for the value effect. In addition, opponents argue that the line between index-based management and active management is blurry because the additional cost of time and effort necessary to research diverse fundamentals must be accounted for.

In summary, there is a large variety of index strategies. This is caused through 'key trade-offs'; breadth versus inevitability, rebalancing versus turnover costs, and rules versus sampling value judgements, all of which every index strategy has to balance (Broby, 2011). Hence, some may deliver higher returns 
and a lower CAPM beta, which enable an investor's exposure to either more return or less risk (Arnott et al., 2010).

Table 1. Weightings in different Commodity Indices

\begin{tabular}{|c|c|c|c|c|c|c|}
\hline & & $\mathbf{R J} / \mathbf{C R B}^{\mathrm{a}}$ & CCI & RICI & BCI & S\&P GSCI \\
\hline \multicolumn{7}{|c|}{ Hard commodities } \\
\hline \multirow[t]{5}{*}{ Energy } & Brent/Crude Oil & $23.00 \%$ & $5.88 \%$ & $35.00 \%$ & $15.00 \%$ & $49.31 \%$ \\
\hline & Natural Gas & $6.00 \%$ & $5.88 \%$ & $3.00 \%$ & $10.42 \%$ & $2.03 \%$ \\
\hline & RBOB Gasoline & $5.00 \%$ & & $3.00 \%$ & $3.46 \%$ & $5.02 \%$ \\
\hline & Heating Oil & $5.00 \%$ & $5.88 \%$ & $1.80 \%$ & $3.52 \%$ & $5.13 \%$ \\
\hline & Gas Oil & & & $1.20 \%$ & & $8.11 \%$ \\
\hline \multirow[t]{10}{*}{ Metals } & Aluminium & $6.00 \%$ & & $4.00 \%$ & $4.91 \%$ & $2.12 \%$ \\
\hline & Copper & $6.00 \%$ & $5.88 \%$ & $4.00 \%$ & $7.28 \%$ & $3.24 \%$ \\
\hline & Gold & $6.00 \%$ & $5.88 \%$ & $3.00 \%$ & $10.82 \%$ & $3.05 \%$ \\
\hline & Lead & & & $2.00 \%$ & & $0.38 \%$ \\
\hline & Silver & $1.00 \%$ & $5.88 \%$ & $2.00 \%$ & $3.90 \%$ & $0.49 \%$ \\
\hline & Zinc & & & $2.00 \%$ & $2.52 \%$ & $0.52 \%$ \\
\hline & Platinum & & $5.88 \%$ & $1.80 \%$ & & \\
\hline & Nickel & $1.00 \%$ & & $1.00 \%$ & $2,24 \%$ & $0.58 \%$ \\
\hline & Tin & & & $1.00 \%$ & & \\
\hline & Palladium & & & $0.30 \%$ & & \\
\hline \multicolumn{7}{|c|}{ Soft commodities } \\
\hline \multirow[t]{4}{*}{ Grain } & Corn & $6.00 \%$ & $5.88 \%$ & $4.75 \%$ & $7.05 \%$ & $4.66 \%$ \\
\hline & Wheat & $1.00 \%$ & $5.88 \%$ & $5.75 \%$ & $4.75 \%$ & $3.92 \%$ \\
\hline & Milling Wheat & & & $1.00 \%$ & & \\
\hline & Soybeans & $6.00 \%$ & $5.88 \%$ & $3.50 \%$ & $5.49 \%$ & $2.63 \%$ \\
\hline \multirow[t]{3}{*}{ Cattle } & Live Cattle & $6.00 \%$ & $5.88 \%$ & $2.00 \%$ & $3.28 \%$ & $2.71 \%$ \\
\hline & Lean Hogs & $1.00 \%$ & $5.88 \%$ & $1.00 \%$ & $1.90 \%$ & $1.52 \%$ \\
\hline & Feeder Cattle & & & & & $0.49 \%$ \\
\hline \multirow{14}{*}{$\begin{array}{l}\text { Softs/ } \\
\text { Agriculture }\end{array}$} & Sugar & $5.00 \%$ & $5.88 \%$ & $1.00 \%$ & $3.88 \%$ & $1.90 \%$ \\
\hline & White Sugar & & & $1.00 \%$ & & \\
\hline & Cotton & $5.00 \%$ & $5.88 \%$ & $4.20 \%$ & $1.76 \%$ & $1.12 \%$ \\
\hline & Coffee & $5.00 \%$ & $5.88 \%$ & $2.00 \%$ & $2.44 \%$ & $0.83 \%$ \\
\hline & Cocoa & $5.00 \%$ & $5.88 \%$ & $1.00 \%$ & & $0.23 \%$ \\
\hline & Orange Juice & $1.00 \%$ & $5.88 \%$ & $0.60 \%$ & & \\
\hline & Soybean Oil & & & $2.00 \%$ & $2.74 \%$ & \\
\hline & Rapeseed & & & $1.00 \%$ & & \\
\hline & Rubber & & & $1.00 \%$ & & \\
\hline & Rice & & & $0.75 \%$ & & \\
\hline & Soybean Meal & & & $0.75 \%$ & $2.60 \%$ & \\
\hline & Milk Class III & & & $0.10 \%$ & & \\
\hline & Oats & & & $0.50 \%$ & & \\
\hline & Lumber & & & $1.00 \%$ & & \\
\hline
\end{tabular}

${ }^{a}$ Note: The Reuters/Jeffries CRB Futures Index (RJ/CRB) is originally sorted in four categories, which differ from the classification in this representation. Index compilations are as of 2012. For simplification and consistency we break down all indices to general classification of the constituents. 
When regarding another increasingly important category of commodity indices, science as well as practice trail far behind. This class of asset indices, which should provide information about commodity market trends, should serve as performance benchmarks and provide investability in form of passive investment opportunities, is sadly lacking a comparable and objective weighting criterion, which is based on theory. To obtain a deeper insight into the state of the art in construction of commodity indices, the most important representatives and their selections as well as weightings are presented in Table 1.

First of all, the large differences in the selection of commodities and their weightings should be noted. There may be a variety of reasons for this heterogeneity. The original CRB index was set up in 1957 by the Commodity Research Bureau (CRB) and is the oldest commodity index on which financial products are emitted. The index has since been modified several times over the years. The latest reconstruction in 2005, however, resulted in two successors. The main subsequent index was renamed to Thomson Reuters/Jefferies CRB Index (RJ/CRB). It is compiled of 19 commodities, sorted into four specific groups: Petroleum based products, liquid assets, highly liquid assets, and diverse commodities. Different weights are assigned to these categories in order to reflect the economic importance of each group. Within those categories constituents are basically equally weighted (Thomson Reuters, 2013). Besides the RJ/CRB, the original CRB index has since been continued under a second manifestation, the Continuous Commodity Index (CCI). In this index the 17 commodities initially compiled in 1957 are still equally weighted. Another index, with 37 commodities covering the broadest range, is the Rogers International Commodity Index (RICI). Within this index, components are weighted and selected yearly, based on the decisions and assessment of a committee, convened especially for this purpose, chaired by Jim Rogers, commodity expert and founder. His vision is to a) reflect commodities' importance in world trade based on consumption and b) to replicate current price levels for a wide range of materials (Rogers, 2015). Hence, this approach could be interpreted as a purely fundamental weighting. The youngest among the considered indices is the Bloomberg Commodity Index (BCI), originally launched in 1999. Until its acquisition through the UBS Group in 2009, the index was operated by the AIG Group under the better-known title, the "Dow Jones AIG Commodity Index" (DJ/AIG), followed by another renaming to "Bloomberg Commodity Index" in 2014. Currently, it consists of 20 commodities. The weighting of its index components, again, aims to show the respective economic importance of each commodity to the global economy. Liquidity, production, and trading volume serve as a basis for assessing each individual significance. Consequently, the scheme also resembles fundamental weighting. The last, but presumably most important index with the largest market share of the considered indices (Doyle et al., 2007), is the former Goldman Sachs Commodity Index (GSCI). Also this index was renamed to S\&P GSCI in 2007, after the acquisition by Standard \& Poor's. The S\&P GSCI is a composition of 24 commodities, which are weighted by five-year averages of their annual production volumes. Goldman Sachs asserts that this weighting scheme, based on world production of each material, represents the closest approach to a market capitalization standard within equity markets (Goldman Sachs, 2015). Nevertheless, the methodology of weighting based on world production is another fundamental weighting scheme 
and by far no cap-based indexation, as world production is not directly linked to market capitalization. Goldman Sachs' statement, however, clearly shows the lack of and need for a market capitalization weighting within commodity indexation.

To summarize, for indices in general and especially for commodity indices, there is a variety of different compilations, weightings, and selections. However, it is absolutely unclear which approach is best. A large number of indices bear resemblances to fundamental weighting, thereby applying different criteria. However, the dominant approach in equity index construction, market capitalization indexation, is the best in an efficient market setting according to Broby (2007) is sadly lacking in practice and has not been implemented in scientific literature until now. The reason is the difficulty and complexity of determining the "market capitalization" of a commodity. While for stocks the current market value and the number of shares are directly and exactly observable, this is not the case for commodities. In order to determine the equivalent to the number of shares, one has to approximate the "total investable amount" of natural resources.

In this paper, we take on this challenging task of determining the market value of commodities in order to create a market capitalization based commodity index, in line with the capital market theory. We present a straight forward approach building on the discounted cash-flow model to assess the amount of capital dedicated to holding the earth's overall investable amount of hard and soft commodities. These results are used to determine objective and substantiated index weights.

Our results show that a commodity index using market capitalization as its weighting criterion performs significantly better in terms of risk-return proposition. The comparison of index weightings to prominent existing commodity indices demonstrates that aluminium, silver, natural gas, and the majority of soft commodities are overvalued in existing indices, whereas oil and its derivatives are significantly underrepresented. Regarding the Sharpe-ratio, which according to the efficient market theory is the most suitable performance measure the presented commodity index offers attractive risk-return characteristics compared to existing indices. This finding has important implications for both, scientists and practitioners. For practitioners, it could be interesting to follow this approach and launch a commodity index based on market-capitalization and thereby address the increasing demand for indirect investment possibilities via index funds. As described above, there is an intense debate on the question how (commodity) indices should be constructed and weighted. Our results support the capital market theory and thereby the market cap weighting, as the MCCI outperforms other indices following different weighting criterions such as equal weighting and different fundamental weighting schemes.

\section{Theoretical Approach}

To apply the market capitalization criterion for commodities in a representative fashion, we must determine and assess the total amount of capital dedicated to holding a commodity (Broby, 2007). Therefore, 
for each commodity the total investable amount available to an investor have to be determined. Theoretically, the total investable amount of a commodity involves, among others, investments in: Physical commodities, financial derivatives, mines, producing companies, farmland, etc. Based on this amount, one can use the current and expected future market prices of the commodity to assess the total market value of a resource's overall stock.

An important challenge at this point is to identify those investment opportunities that represent the resource's overall stock. Many forms of financial investments (such as derivatives or investments into mining companies), for instance, basically depend on the market value of the respective underlying commodity and do not generate additional value beyond the intrinsic value of it; e.g. derivatives improve investability, but long and short positions in the market always offset each other. Therefore, we assess all cash flows which are attainable from the physical underlying itself, e.g.: natural resources.

As there is a fundamental difference between renewable and non-renewable commodities, concerning their future potential supply, we have to apply different valuation procedures for these two groups. For non-renewable commodities, the total investable amount from a general perspective depends on three main determinants:

\author{
I. World resources \\ II. Processed raw material (opportunity for secondary production) \\ III. Current stocks
}

Hence, to measure the total investable amount of a commodity, referring to McKelvey (1974), we assess the total physical resources base, including reserves, undiscovered, and subeconomic resources (see Figure 1). This number also provides the advantage that it fluctuates less than the assessments of reserves, due to its lower dependency on technical progress. For instance, the reserves of oil have been nearly constant the last 30 years, despite consumption increases from year to year, although the total resource base of oil obviously is declining, which is due to the technical progress and exploration of new oil reserves. Therefore, the resource base is the more suitable number in order to assess the total investable amount. 
Figure 1. Classification of mineral resources based on McKelvey (1974)

\section{Total resources}

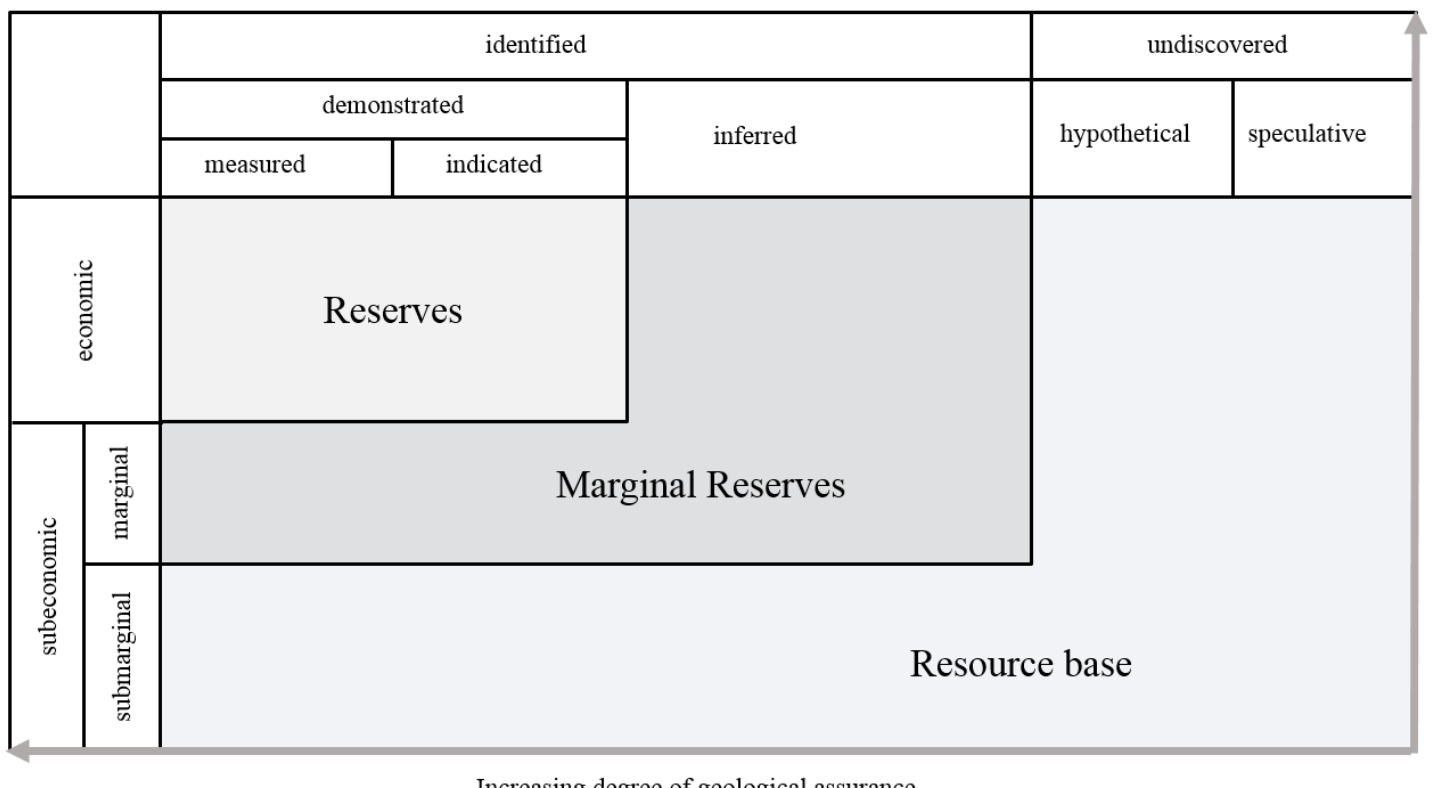

In addition to the resource base, one must account for current stock, simply given by inventory levels and the possibility of secondary production, which can be determined by the possible recycling rate and the amount of by now processed material.

In general, the market value of any investment vehicle, no matter if it is an enterprise, a financial derivative, or a commodity, can be calculated by discounting its expected future cash flows. Therefore, we calculate the annual revenues, determined by market prices, demand, recyclable quantities, cash costs, recycling costs, and investment costs of each commodity until its resources are expected to be completely exhausted. As the resource base and relevant costs are rather deterministic, demand, as the driving force behind production, is supposed to be the most influential factor for yearly turnover (RosenauTornow et al., 2009). According to the market equilibrium theory, supply and demand are balanced in the long run. Consequently, the total commodity supply, consisting of primary production and recycling quantities, meets the respective demand. Thus, the total investable amount of a commodity (in other words physical supply) determines the capacity restriction, whereas the yearly demand determines the distribution of sales over time and hence the time threshold of degradation. This is represented by the following net present value formula (1):

$$
M V_{i}=\sum_{t 0}^{T} \frac{p_{\mathrm{it}} \cdot y_{\mathrm{it}}-c_{\mathrm{it}} \cdot\left(1-s p_{i}\right) \cdot y_{\mathrm{it}}-c_{\mathrm{sp}} \cdot s p_{i} \cdot y_{\mathrm{it}}-I_{\mathrm{it}}}{\left(1+r_{i t}\right)^{\mathrm{t}}}
$$

Where $p_{\mathrm{it}}$ is the price, $c_{\mathrm{it}}$ are cash costs, $c_{\mathrm{sp}}$ are costs of secondary production (recycling), and $I_{\mathrm{it}}$ the investment costs of a commodity $i$. Moreover, the yearly recycling rate is denoted by $s p_{i}$ and the discount rate by $r_{i t}$. The annual sales volume $y_{\text {it }}$ (demand-driven) is the sum of the yearly recycling amount $\left(s p_{i} *\right.$ 
$\left.y_{\text {it }}\right)$ and the primary production $\left(1-s p_{i}\right) * y_{\text {it. }} T$ denotes the year in which the resource base of a commodity is expected to be exhausted, see formula (2). Hence, it is possible to calculate the total value of a commodity by using existing data.

$$
T=\underset{\tau}{\operatorname{argmax}} \sum_{t=0}^{\tau} y_{t} \leq \text { Resources }
$$

For renewable commodities - largely agricultural products - an adapted valuation approach, based on the same principle of discounted future cash-flows, is necessary. As these commodities are not finite and cannot be recycled, the generated cash inflow is determined by the yearly sales and the corresponding price. Cash outflows include the total costs for seed, growth and harvesting. Due to the renewability, we adjust formula (1) and determine the total value of those commodities as a perpetual annuity.

$$
M V_{i}=\frac{p_{i t} * y_{i t}-t c_{i t}-I_{i t}}{r_{i}}
$$

$t c_{i t}$ represents the total costs for seed, growth and harvesting. All other variables are the same as in formula (1).

By summing up these market values, we are able to calculate the index value $I$ as well as the respective weight $w_{i}$ in $t_{0}$. The index value over time is then determined by:

$$
I_{t_{k}}=I_{t_{0}} \frac{\sum_{i=1}^{N} M V\left(p_{i, t_{k}}\right)}{\sum_{i=1}^{N} M V\left(p_{i, t_{0}}\right)}=I_{t_{0}} \frac{\sum_{i=1}^{N} p_{i, t_{k}} w_{i, t_{k}}}{\sum_{i=1}^{N} p_{i, t_{0}} w_{i, t_{0}}}
$$

with $I_{t_{0}}$ representing the index value and $w_{i, t_{0}}$ the weights of commodity $i$, each at the base day $t_{0}$. The index value in course of time, after reweighting for new reserve figures, cash costs, etc., will be adjusted by new weights and prices valid at time $t_{k}$.

The presented valuation approach enables the determination of the total value of any commodity, which is necessary for index weighting based on market capitalization. However, another major challenge is to operationalize the determinants described above. In the following we describe an example application of this valuation approach using real world data.

\section{Example Application}

In the following section we first describe the selection of commodities used in this example application. Based on this, we explain the data sources and the data processing. Finally, the market capitalization based commodity index (MCCI) is calculated and evaluated by comparison with existing commodity indices, concerning the single weights as well as historical performance. 


\section{Commodity selection}

Within existing commodity indices, different raw materials are covered, e.g. representatives of the energy, corn, base metal, and live cattle industry. Technically, all types of commodities should be included to implement a complete market index. However, due to the state of available data, it is not possible to cover the full range of natural resources. Still, by considering the most important commodities we are able to compile an extensive set (see Table 2), which provides a reliable picture of this novel approach to commodity indexation.

All commodities written in black are part of our exemplary application. These consist of six metals: Copper, gold, silver, nickel, zinc, and aluminium; and five energy commodities, including crude oil, natural gas, heating oil, gasoline, and gas oil; all of which are the most prevalent hard commodities in the observed commodity indices. Furthermore, this selection represents the entire metallic elements included within the Bloomberg Commodity Index and includes representatives of the two important groups, industry metals and precious metals. Additionally, most of the soft commodities, i.e. three types of grain, live cattle, and lean hogs are included in our exemplary application, leading to a representative compilation within the MCCI. 
Table 2. Frequency of commodities in current commodity indices

\begin{tabular}{|c|c|c|c|c|c|c|c|}
\hline & & $\mathrm{RJ} / \mathrm{CRB}^{\mathrm{a}}$ & CCI & RICI & BCI & $\begin{array}{l}\text { S\&P } \\
\text { GSCI } \\
\end{array}$ & Frequency \\
\hline \multicolumn{8}{|c|}{ Hard commodities } \\
\hline \multirow{5}{*}{ Energy } & Brent/Crude Oil & $\checkmark$ & $\checkmark$ & $\checkmark$ & $\checkmark$ & $\checkmark$ & 5 \\
\hline & Natural Gas & $\checkmark$ & $\checkmark$ & $\checkmark$ & $\checkmark$ & $\checkmark$ & 5 \\
\hline & RBOB Gasoline & $\checkmark$ & & $\checkmark$ & $\checkmark$ & $\checkmark$ & 4 \\
\hline & Heating Oil & $\checkmark$ & $\checkmark$ & $\checkmark$ & $\checkmark$ & $\checkmark$ & 5 \\
\hline & Gas Oil & & & $\checkmark$ & & $\checkmark$ & 2 \\
\hline \multirow{10}{*}{ Metals } & Aluminium & $\checkmark$ & & $\checkmark$ & $\checkmark$ & $\checkmark$ & 4 \\
\hline & Copper & $\checkmark$ & $\checkmark$ & $\checkmark$ & $\checkmark$ & $\checkmark$ & 5 \\
\hline & Gold & $\checkmark$ & $\checkmark$ & $\checkmark$ & $\checkmark$ & $\checkmark$ & 5 \\
\hline & Lead & & & $\checkmark$ & & $\checkmark$ & 2 \\
\hline & Silver & $\checkmark$ & $\checkmark$ & $\checkmark$ & $\checkmark$ & $\checkmark$ & 5 \\
\hline & Zinc & & & $\checkmark$ & $\checkmark$ & $\checkmark$ & 3 \\
\hline & Platinum & & $\checkmark$ & $\checkmark$ & & & 2 \\
\hline & Nickel & $\checkmark$ & & $\checkmark$ & $\checkmark$ & $\checkmark$ & 4 \\
\hline & Tin & & & $\checkmark$ & & & 1 \\
\hline & Palladium & & & $\checkmark$ & & & 1 \\
\hline \multicolumn{8}{|c|}{ Soft commodities } \\
\hline \multirow{4}{*}{ Grain } & Corn & $\checkmark$ & $\checkmark$ & $\checkmark$ & $\checkmark$ & $\checkmark$ & 5 \\
\hline & Wheat & $\checkmark$ & $\checkmark$ & $\checkmark$ & $\checkmark$ & $\checkmark$ & 5 \\
\hline & Milling Wheat & & & $\checkmark$ & & & 1 \\
\hline & Soybeans & $\checkmark$ & $\checkmark$ & $\checkmark$ & $\checkmark$ & $\checkmark$ & 5 \\
\hline \multirow{3}{*}{ Cattle } & Live Cattle & $\checkmark$ & $\checkmark$ & $\checkmark$ & $\checkmark$ & $\checkmark$ & 5 \\
\hline & Lean Hogs & $\checkmark$ & $\checkmark$ & $\checkmark$ & $\checkmark$ & $\checkmark$ & 5 \\
\hline & Feeder Cattle & & & & & $\checkmark$ & 1 \\
\hline \multirow{14}{*}{$\begin{array}{c}\text { Softs/ } \\
\text { Agricul- } \\
\text { ture }\end{array}$} & Sugar & $\checkmark$ & $\checkmark$ & $\checkmark$ & $\checkmark$ & $\checkmark$ & 5 \\
\hline & White Sugar & & & $\checkmark$ & & & 1 \\
\hline & Cotton & $\checkmark$ & $\checkmark$ & $\checkmark$ & $\checkmark$ & $\checkmark$ & 5 \\
\hline & Coffee & $\checkmark$ & $\checkmark$ & $\checkmark$ & $\checkmark$ & $\checkmark$ & 5 \\
\hline & Cocoa & $\checkmark$ & $\checkmark$ & $\checkmark$ & & $\checkmark$ & 4 \\
\hline & Orange Juice & $\checkmark$ & $\checkmark$ & $\checkmark$ & & & 3 \\
\hline & Soybean Oil & & & $\checkmark$ & $\checkmark$ & & 2 \\
\hline & Rapeseed & & & $\checkmark$ & & & 1 \\
\hline & Rubber & & & $\checkmark$ & & & 1 \\
\hline & Rice & & & $\checkmark$ & & & 1 \\
\hline & Soybean Meal & & & $\checkmark$ & $\checkmark$ & & 2 \\
\hline & Milk Class III & & & $\checkmark$ & & & 1 \\
\hline & Oats & & & $\checkmark$ & & & 1 \\
\hline & Lumber & & & $\checkmark$ & & & 1 \\
\hline
\end{tabular}

Note: Commodities greyed out are not included within the exemplary application of the MCCI.

In summary, the most important commodities listed within major commodity indices are included in the following application in order to provide a reliable picture of market capitalization based commodity indexing. 


\section{Data and processing}

Although we are able to collect broad data for the commodities noted above, different information sources are necessary as data availability for the required commodity fundamentals is rather poor (see Table A1 in the appendix).

The $1^{\text {st }}$ of January 2013 serves as starting date $t_{0}$ for the subsequent calculation of $y_{0}, c_{0}$, and $p_{0}{ }^{\dagger}$. An overview of input data is shown in Table 3 for non-renewables and in Table 4 for renewables. Market values for the energy derivatives are calculated proportionately to the respective world production, based on the value of crude oil (gasoline at $26.6 \%$, heating oil at $13.7 \%$, and gas oil at $20.1 \%$ ).

Data and estimates of future demand for commodities originate from studies dealing with relevant prediction (see Angerer et al. 2009; Angerer et al., 2010; RWO Essen/Fraunhofer ISI/BGR 2005; IEA, 2009). When predictions of annual future demands are not available, but rather in intervals, a linear trend is assumed. If such studies are not available, a simple linear regression model, based on demand figures, is applied to determine demand forecasts.

Annual prices - apart from $\mathrm{p}_{\mathrm{i} 0}$ - are extrapolated using a historical twenty-year average yearly rate of return (1993 to 2013) of the specific commodity. To estimate the present value of these future cash flows, we determine a commodity specific discount rate using a peer group approach (e.g. see Damodaran, 2001). Specifically, the average return of the top ten listed commodity producers for each material over the last twenty years is calculated (data from ThomsonReuters), thereby following Fama and French (1997), Gergory and Michou (2009), as well as Cochrane (2011).

Cash and investment costs are assumed to increase alongside inflation. Other cost-increasing effects, such as decrease in quality or the cost-decreasing effect caused through technological progress, are assumed to offset each other (Solow,1974; Hartwick, 1977) and are therefore not considered. This assumption also aligns with the central conclusion of Slade (1982), who states that commodities in the long-term follow a u-shaped price pattern. Investment costs are taken into account on an annual basis, considering cash outflows for loan repayments, new investments, or repair expenses.

Due to insufficient data availability, current stocks are not considered in the estimation of the global resource base. However, as the amount of current stocks compared to the amount of total reserves is marginal, the effect of this assumption is negligible. Regarding data of world resources for gold and silver, the only figures for the U.S. are published by the U.S. Geological Survey. Therefore, we calculate the world resource proxies according to their ratios of occurrence in the earth's crust, in comparison to those of other raw materials; see Lide (2005).

The yearly recycling quantity is calculated based on the recycled amount of each material in the U.S. in 2013. This number serves as a proxy for the global recycling rate and is assumed to be constant, until

\footnotetext{
${ }^{\dagger}$ If data sources do not contain current values for this starting date but older information is available, we adjust the numbers by inflation to approximate a comparable starting value.
} 
the total depletion of a raw material. Regarding oil, gas, and its variations, recycling is not considered because energy commodities are for the large part used as fuels and hence only a small proportion, e.g. from plastics, can be recycled. In addition, the resulting recycled material is in most cases of lower quality, as it is down-cycled. Cash costs of secondary production have been adjusted by inflation, in case of differing survey dates. Generally, recycling costs for copper amount to $90 \%$ of the cash costs (Benefits of Recycling, 2013). As the data availability of recycling costs is very limited, we suppose this value to be a general proxy for a first preliminary approach. This assumption is acceptable, as because of higher recycling costs, mining would be preferred instead of recycling. Lower recycling costs are not realistic as well, because of the huge efforts connect to recycling (e.g. the demolition of buildings, chemical reactions, or disassembly of vehicles).

Concerning investment costs for metals, the amount of costs is, as generally assessed for an average period of ten years (Metal Radar, 2013), allocated linearly in order to obtain an annual investment cost. For energy commodities, specific data for investment costs is available.

Table 3. Key figures of input data for non-renewable commodities ${ }^{a, b}$

\begin{tabular}{cccccccc}
\hline Data & $\begin{array}{c}\text { Resources } \\
\text { (mil. } \\
\text { tonnes) }\end{array}$ & $\begin{array}{c}\text { Price in } t_{0} \\
\text { (per unit) }\end{array}$ & $\begin{array}{c}\text { Average } \\
\text { rate of re- } \\
\text { turn }\end{array}$ & $\begin{array}{c}\text { Investment } \\
\text { costs in } t_{0} \\
\text { (bn) }\end{array}$ & $\begin{array}{c}\text { Cash costs } \\
\text { in } t_{0} \text { (per } \\
\text { unit) }\end{array}$ & $\begin{array}{c}\text { Recycling } \\
\text { rate }\end{array}$ & $\begin{array}{c}\text { Discount } \\
\text { rate }\end{array}$ \\
\hline Copper & 3,000 & 7,907 & $13.09 \%$ & 20 & 1,867 & $10.00 \%$ & $13.09 \%$ \\
Nickel & 130 & 16,998 & $10.75 \%$ & 6 & 8,050 & $43.00 \%$ & $9.42 \%$ \\
Gold & 0.200 & $53,499,264$ & $9.35 \%$ & 12 & $20,857,957$ & $35.00 \%$ & $6.67 \%$ \\
Aluminium & 9,170 & 2,041 & $6.54 \%$ & - & 1,867 & $35.00 \%$ & $17.72 \%$ \\
Silver & 3.75 & 997,316 & $14.01 \%$ & 0.817 & 291,580 & $25.00 \%$ & $18.85 \%$ \\
Zinc & 1,900 & 2,050 & $8.66 \%$ & 1 & 1,330 & $16.00 \%$ & $14.12 \%$ \\
Crude Oil & $\begin{array}{c}331,000 \\
\text { (mil. barrel) }\end{array}$ & 93 & $9.29 \%$ & 178 & 56 & - & $9.08 \%$ \\
Natural Gas & $\begin{array}{c}3,560 \\
\text { (mil. barrel) }\end{array}$ & 19 & $12.96 \%$ & 0.103 & 7 & - & $9.10 \%$ \\
\hline
\end{tabular}

a Note: Data written italic are further computed as described below

${ }^{\mathrm{b}}$ Prices and Costs in US

For renewable commodities the calculation of the total market value follows the same principle, but a few adjustments are necessary. We use the "Net Value of Production" data from FAOSTAT as a proxy for the yearly cash flow (numerator of formula 2). This figure takes into account deductions for feed and seed, and uses international commodity prices. For further details concerning the calculation of these numbers, see FAOSTAT (2015). The discount rate is calculated using a peer group analogously to the calculation of hard commodities. As a peer group, we use 10 years of historic returns from the MSCI ACWI Select Agriculture Producers Investable Market Index. In order to account for future price increases, we extrapolate the future "Net Value of Production" on the basis of its historic twenty-year average growth rate, which is in accordance with the procedure for non-renewable commodities. 
Table 4. Key figures of input data for renewable commodities

\begin{tabular}{ccc}
\hline Data & $\begin{array}{c}\text { Net Production } \\
\text { Value (1.000 Int. \$) }\end{array}$ & Discount rate \\
\hline Corn & $53,604,464.29$ & $17.29 \%$ \\
Wheat & $79,285,035.50$ & $19.45 \%$ \\
Soybeans ${ }^{\mathrm{a}}$ & $17,156,573,456.77$ & $13.01 \%$ \\
Live Cattle & $169,476,915.56$ & $19.33 \%$ \\
Lean Hogs & $166,801,085.79$ & $18.69 \%$ \\
Sugar & $68,665,922.64$ & $18.98 \%$ \\
Cotton & $37,095,127.01$ & $18.01 \%$ \\
Coffee & $9,483,271.93$ & $18.09 \%$ \\
Cocoa & $5,195,774.82$ & $16.76 \%$ \\
Oranges & $13,182,837.07$ & $18.93 \%$ \\
Rapeseed & $16,310,778.02$ & $23.06 \%$ \\
Rubber & $13,091,393.21$ & $16.53 \%$ \\
Rice & $185,579,591.35$ & $18.55 \%$ \\
Milk & $187,277,186.47$ & 18.46 \\
Oats & $562,298.92$ & $15.00 \%$
\end{tabular}

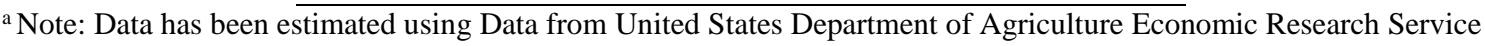
(USDA ERS) from year 2012

Based on this data collection and the described assumptions, we are able to practically apply the theoretical commodity valuation approach, thereby building the basis for a market capitalization weighted index, which is presented in the next section.

\section{Results}

Market values of each commodity and the corresponding weightings of the presented market capitalization based commodity index (MCCI) are presented in Table 5. Oil represents the dominating constituent in the market capitalization weighted index, with a share of $29.2 \%$. Derivative products of oil, such as heating oil (10.2\%), gasoline (19.8\%) and gas oil (15\%), also show high index proportions. The only exception in this group is natural gas, with a marginal share of $0.3 \%$. Reasons for this low weighting of natural gas within the energy group could be its small resource base in comparison to the other oil energy commodities and the quite low price of 18.65 USD per barrel. In total, the energy group accounts for a large index proportion of $74.4 \%$. Regarding metals, gold has the highest index value. Here, a remarkable difference between the spot price of gold and respective costs leads to large expected future surpluses. Copper, one of the most important industrial metals, shows similar importance with a share of $9.40 \%$. In addition, nickel (traded on the LME) accounts for $2.25 \%$. In comparison to these substantive metals and regarding their index weightings, aluminium, zinc, and silver represent, however, only a marginal 
part of the MCCI, amounting for less than $1 \%$ each. In the case of silver, which has a relatively low resource base compared to other commodities, the result lies in a static range of only 48 years, which in combination with a high discount rate leads to a small index weighting.

For zinc, the small difference between price and costs of only 719 USD per ton is the reason for a low market value, although its resource base is very high with 1.9 billion tonnes. The rather surprising result for aluminium, with an index share of only $0.14 \%$, is due to a high discount rate and again a simultaneously low profit of only 174 USD per ton, which cannot be compensated for by the high resource base of 9.2 billion tonnes. In light of these figures, the rather low market values, in connection with minor index weights of zinc, silver, aluminium, and natural gas compared to other commodities, are sound. Although, one would expect higher index weightings for these important industrial resources. Furthermore, each of those three categories of soft commodities only accounts for a weight of less than $1 \%$. This is primarily due to very low net earnings per ton and high discount rates of 15 to $20 \%$. Because of the low exposure of individual soft commodities, they are aggregated according to their main categories in the following evaluation: Grain, cattle, and soft/agriculture.

Table 6 shows the MCCI compilation in comparison to the four major commodity indices introduced before. As shown in Table 6, aluminium, silver, and natural gas, as well as soft commodities in particular, are assessed to be more valuable in existing commodity indices as they would be recommended by the market capitalization based indexation. A comparatively high weighting of oil is represented in most other indices, whereas natural gas in existing fundamental weighting seems overstated. However, the derivative products of oil seem to be rather undervalued.

Regarding metals, the shares of copper, gold, and especially nickel correspond with their proportions in existing commodity indices. For soft commodities, the largest deviations between market capitalization and existing commodity indices can be observed. Here, softs/agricultures and grain show close to $15 \%$ of mean deviation. 
Table 5. Market values and corresponding index weightings

\begin{tabular}{|c|c|c|c|}
\hline & & $\mathrm{MV}^{\mathrm{a}}$ (in Mio. USD) & Value based index weightings \\
\hline \multicolumn{4}{|c|}{ Hard commodities } \\
\hline \multirow{5}{*}{ Energy } & Brent/Crude Oil & $79,752,920$ & $29.20 \%$ \\
\hline & Natural Gas & 800,620 & $0.29 \%$ \\
\hline & RBOB Gasoline & $54,002,982$ & $19.77 \%$ \\
\hline & Heating Oil & $27,826,684$ & $10.19 \%$ \\
\hline & Gas Oil & $40,842,710$ & $14.96 \%$ \\
\hline \multirow{6}{*}{ Metals } & Aluminium & 386,708 & $0.14 \%$ \\
\hline & Copper & $25,670,848$ & $9.40 \%$ \\
\hline & Gold & $30,014,193$ & $10.99 \%$ \\
\hline & Silver & $1,694,021$ & $0.62 \%$ \\
\hline & Zinc & 457,522 & $0.17 \%$ \\
\hline & Nickel & $6,136,459$ & $2.25 \%$ \\
\hline \multicolumn{4}{|c|}{ Soft commodities } \\
\hline \multirow{3}{*}{ Grain } & Corn & 310,005 & $0.11 \%$ \\
\hline & Wheat & 407,747 & $0.15 \%$ \\
\hline & Soybeans & 131,872 & $0.05 \%$ \\
\hline \multirow{2}{*}{ Cattle } & Live Cattle & 876,719 & $0.32 \%$ \\
\hline & Lean Hogs & 892,372 & $0.33 \%$ \\
\hline \multirow{10}{*}{$\begin{array}{l}\text { Softs/ } \\
\text { Agricul- } \\
\text { ture }\end{array}$} & Sugar & 361,832 & $0.13 \%$ \\
\hline & Cotton & 205,942 & $0.08 \%$ \\
\hline & Coffee & 52,416 & $0.02 \%$ \\
\hline & Cocoa & 30,993 & $0.01 \%$ \\
\hline & Orange Juice & 69,636 & $0.03 \%$ \\
\hline & Rapeseed & 70,730 & $0.03 \%$ \\
\hline & Rubber & 79,186 & $0.03 \%$ \\
\hline & Rice & $1,000,454$ & $0.37 \%$ \\
\hline & Milk Class III & $1,014,355$ & $0.37 \%$ \\
\hline & Oats & 3,748 & $0.0014 \%$ \\
\hline
\end{tabular}

${ }^{a}$ Note: MV indicates Market Value;

From Table 6 it can be seen that according to its mean absolute deviation from the MCCI, the S\&P GSCI weighting is the closest with only $6.05 \%$ mean deviation. This is a very interesting fact, as Goldman Sachs, the publisher of the S\&P GSCI, claims that their weighting scheme, by virtue of being based on fundamentals, represents the closest approach to a market capitalization standard within equity markets (Goldman Sachs, 2015). Furthermore, the equally weighted CCI, with 10.29\% mean deviation, differs the most, which is a sound result, as the CCI should have the most different weighting according to its theoretical varying construction. 
Table 6. Comparison of index weightings ${ }^{a, b}$

\begin{tabular}{|c|c|c|c|c|c|c|c|}
\hline Commodity & $\begin{array}{l}\text { MCCI } \\
\text { Index }\end{array}$ & $\mathrm{RJ} / \mathrm{CRB}$ & CCI & RICI & BCI & S\&P GSCI & $\begin{array}{c}\text { Mean } \\
\text { deviation }\end{array}$ \\
\hline Oil & $29.20 \%$ & $\begin{array}{l}23.00 \% \\
(-6.20 \%)\end{array}$ & $\begin{array}{c}6.25 \% \\
(-22.96 \%)\end{array}$ & $\begin{array}{c}38.40 \% \\
(+9.19 \%)\end{array}$ & $\begin{array}{c}15.40 \% \\
(-13.80 \%)\end{array}$ & $\begin{array}{c}49.74 \% \\
(+20.54 \%)\end{array}$ & $(-2.65 \%)$ \\
\hline Natural Gas & $0.29 \%$ & $\begin{array}{c}6.00 \% \\
(+5.71 \%)\end{array}$ & $\begin{array}{c}6.25 \% \\
(+5.95 \%)\end{array}$ & $\begin{array}{c}3.29 \% \\
(+3.00 \%)\end{array}$ & $\begin{array}{c}10.70 \% \\
(+10.40 \%)\end{array}$ & $\begin{array}{c}2.05 \% \\
(+1.75 \%)\end{array}$ & $(+5.36 \%)$ \\
\hline Heating Oil & $19.77 \%$ & $\begin{array}{c}5.00 \% \\
(-14.77 \%)\end{array}$ & $\begin{array}{c}- \\
(-19.77 \%)\end{array}$ & $\begin{array}{c}3.29 \% \\
(-16.48 \%)\end{array}$ & $\begin{array}{c}3.55 \% \\
(-16.22 \%)\end{array}$ & $\begin{array}{c}5.06 \% \\
(-14.71 \%)\end{array}$ & $(-16.39 \%)$ \\
\hline Gasoline & $10.19 \%$ & $\begin{array}{c}5.00 \% \\
(-5.19 \%)\end{array}$ & $\begin{array}{c}6.25 \% \\
(-3.94 \%)\end{array}$ & $\begin{array}{c}1.97 \% \\
(-8.21 \%)\end{array}$ & $\begin{array}{c}3.61 \% \\
(-6.58 \%)\end{array}$ & $\begin{array}{c}5.18 \% \\
(-5.01 \%)\end{array}$ & $(-5.79 \%)$ \\
\hline Gas Oil & $14.96 \%$ & $\begin{array}{c}- \\
(-14.96 \%)\end{array}$ & $\begin{array}{c}- \\
(-14.96 \%)\end{array}$ & $\begin{array}{c}1.32 \% \\
(-13.64 \%)\end{array}$ & $\begin{array}{c}- \\
(-14.96 \%)\end{array}$ & $\begin{array}{c}8.18 \% \\
(-6.77 \%)\end{array}$ & $(-13.06 \%)$ \\
\hline Copper & $9.40 \%$ & $\begin{array}{c}6.00 \% \\
(-3.40 \%)\end{array}$ & $\begin{array}{c}6.25 \% \\
(-3.15 \%)\end{array}$ & $\begin{array}{c}4.39 \% \\
(-5.01 \%)\end{array}$ & $\begin{array}{c}7.47 \% \\
(-1.93 \%)\end{array}$ & $\begin{array}{c}3.27 \% \\
(-6.13 \%)\end{array}$ & $(-3.92 \%)$ \\
\hline Aluminium & $0.14 \%$ & $\begin{array}{c}6.00 \% \\
(+5.86 \%)\end{array}$ & $\begin{array}{c}- \\
(-0.14 \%)\end{array}$ & $\begin{array}{c}4.39 \% \\
(+4.25 \%)\end{array}$ & $\begin{array}{c}5.04 \% \\
(+4.90 \%)\end{array}$ & $\begin{array}{c}2.14 \% \\
(+2.00 \%)\end{array}$ & $(+3.37 \%)$ \\
\hline Nickel & $2.25 \%$ & $\begin{array}{c}1.00 \% \\
(-1.25 \%)\end{array}$ & $\begin{array}{c}- \\
(-2.25 \%)\end{array}$ & $\begin{array}{c}1.10 \% \\
(-1.15 \%)\end{array}$ & $\begin{array}{c}2.30 \% \\
(+0.05 \%)\end{array}$ & $\begin{array}{c}0.59 \% \\
(-1.66 \%)\end{array}$ & $(-1.25 \%)$ \\
\hline Zinc & $0.17 \%$ & $\begin{array}{c}- \\
(-0.17 \%)\end{array}$ & $\begin{array}{c}- \\
(-0.17 \%)\end{array}$ & $\begin{array}{c}2.19 \% \\
(+2.03 \%)\end{array}$ & $\begin{array}{c}2.59 \% \\
(+2.42 \%)\end{array}$ & $\begin{array}{c}0.52 \% \\
(+0.36 \%)\end{array}$ & $(+0.89 \%)$ \\
\hline Gold & $10.99 \%$ & $\begin{array}{c}6.00 \% \\
(-4.99 \%)\end{array}$ & $\begin{array}{c}6.25 \% \\
(-4.74 \%)\end{array}$ & $\begin{array}{c}3.29 \% \\
(-7.70 \%)\end{array}$ & $\begin{array}{c}11.11 \% \\
(+0.12 \%)\end{array}$ & $\begin{array}{c}3.08 \% \\
(-7.91 \%)\end{array}$ & $(-5.05 \%)$ \\
\hline Silver & $0.62 \%$ & $\begin{array}{c}1.00 \% \\
(+0.38 \%)\end{array}$ & $\begin{array}{c}6.25 \% \\
(+5.63 \%)\end{array}$ & $\begin{array}{c}2.19 \% \\
(+1.57 \%)\end{array}$ & $\begin{array}{c}4.00 \% \\
(+3.38 \%)\end{array}$ & $\begin{array}{c}0.49 \% \\
(-0.13 \%)\end{array}$ & $(+2.17 \%)$ \\
\hline Grain & $0.31 \%$ & $\begin{array}{c}13.00 \% \\
(+12.69 \%)\end{array}$ & $\begin{array}{c}18.74 \% \\
(+18.43 \%)\end{array}$ & $\begin{array}{c}15.36 \% \\
(+15.05 \%)\end{array}$ & $\begin{array}{c}17.75 \% \\
(+17.44 \%)\end{array}$ & $\begin{array}{c}11.31 \% \\
(+11.00 \%)\end{array}$ & $(+14.92 \%)$ \\
\hline Cattle & $0.65 \%$ & $\begin{array}{c}7.00 \% \\
(+6.35 \%)\end{array}$ & $\begin{array}{c}12.50 \% \\
(+11.85 \%)\end{array}$ & $\begin{array}{c}3.29 \% \\
(+2.64 \%)\end{array}$ & $\begin{array}{c}5.32 \% \\
(+4.67 \%)\end{array}$ & $\begin{array}{c}4.27 \% \\
(+3.62 \%)\end{array}$ & $(+5.83 \%)$ \\
\hline $\begin{array}{c}\text { Soft/ } \\
\text { Agriculture }\end{array}$ & $1.06 \%$ & $\begin{array}{r}21.00 \% \\
(+19.94 \%) \\
\end{array}$ & $\begin{array}{r}31.24 \% \\
(+30.18 \%) \\
\end{array}$ & $\begin{array}{r}15.52 \% \\
(+14.47 \%) \\
\end{array}$ & $\begin{array}{r}11.11 \% \\
(+10.05 \%) \\
\end{array}$ & $\begin{array}{r}4.12 \% \\
(+3.06 \%) \\
\end{array}$ & $(+15.54 \%)$ \\
\hline $\begin{array}{l}\text { Mean abs. } \\
\text { Deviation }\end{array}$ & & $7.28 \%$ & $10.29 \%$ & $7.46 \%$ & $7.64 \%$ & $6.05 \%$ & \\
\hline
\end{tabular}

aNote: The weights of the current commodity indices are adjusted on the assumption that only elements of the MCCI Index are included in the whole index.

${ }^{\mathrm{b}}$ As individual soft commodities have low exposure (see Table 5), they are aggregated to the three groups: grain, cattle and soft/agriculture.

Summing up, the market capitalization based commodity indexation approach, as presented in this work, recommends different commodity weightings. Particularly oil, gasoline, gas oil, and almost all soft commodities are currently undervalued, and aluminium, silver, as well as natural gas are overvalued in existing commodity indices. 


\section{Evaluation and robustness}

To evaluate and validate the presented commodity valuation approach and its results, we first compare the historical performance of the presented market capped index with existing commodity indices. Figure 2 shows the relative development of the index values for the MCCI and major commodity indices starting in 2000. For RJ/CRB, CCI, RICI, BCI, and S\&P GSCI, we used the reported index performance from Thomson Reuters. The MCCI is calculated as follows: The weightings of the year 2013 described above are used as reference. For each commodity, monthly price changes from January 2000 to December 2015, observed from World Bank Commodity Price Data, Bloomberg and the U.S. Energy Information Administration (EIA) are used to approximate the yearly changes in market capitalization. Based on these market capitalizations, the individual commodity weightings are recalculated each month, which are then used to calculate the historical performance of the MCCI.

Figure 2. Comparison of relative index development over time

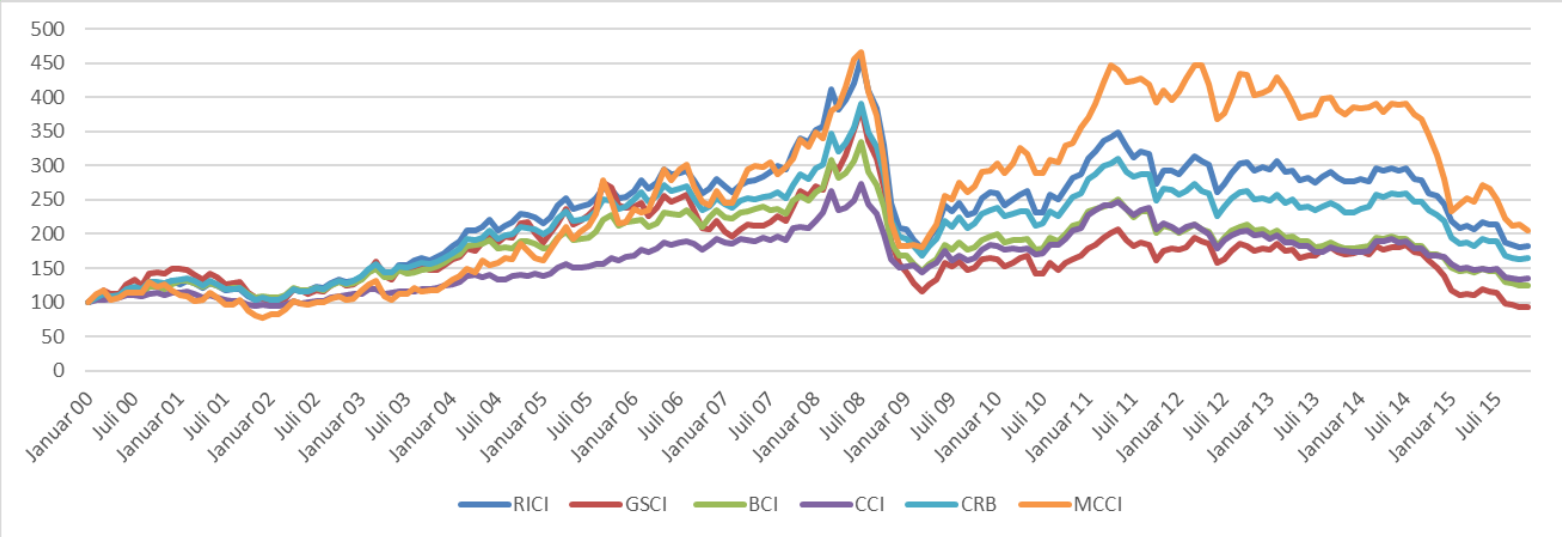

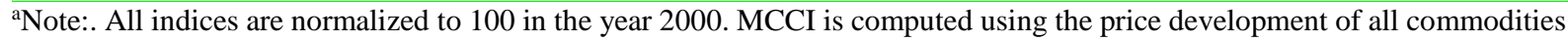
included and yearly re-weighting. The other indices are calculated using the reported index performance from Thomson Reuters.

As can be seen from figure 2 there are up and downs within the last decade, however, the MCCI during recent years shows an outperformance compared to the other indices. To get a deeper insight into the risk and return properties of the different indices, Table 7 provides further performance characteristics. The equal weighted average of the existing indices serves as the benchmark return series used for information ratios and tracking errors. 
Table 7. Performance characteristics - risk and return on whole time period

\begin{tabular}{|c|c|c|c|c|c|c|}
\hline Index & $\begin{array}{c}\text { Monthly } \\
\text { average } \\
\text { return }\end{array}$ & $\begin{array}{c}\text { monthly } \\
\text { standard } \\
\text { deviation }\end{array}$ & $\begin{array}{l}\text { Sharpe- } \\
\text { ratio }^{\mathrm{b}}\end{array}$ & $\begin{array}{l}\text { excess } \\
\text { return }\end{array}$ & $\begin{array}{l}\text { tracking } \\
\text { error }^{\mathrm{d}}\end{array}$ & $\begin{array}{l}\text { information } \\
\text { ratio }^{\mathrm{e}}\end{array}$ \\
\hline$M C C I$ & $0,61 \%$ & $7,26 \%$ & $8,38 \%$ & $0,32 \%$ & $4,39 \%$ & $7,32 \%$ \\
\hline$R J / C R B$ & $0,37 \%$ & $5,25 \%$ & $0,00 \%$ & $0,09 \%$ & $0,55 \%$ & $-2,59 \%$ \\
\hline$C C I$ & $0,23 \%$ & $4,34 \%$ & $5,32 \%$ & $-0,07 \%$ & $2,73 \%$ & $-2,59 \%$ \\
\hline$R I C I$ & $0,44 \%$ & $5,68 \%$ & $7,83 \%$ & $0,20 \%$ & $1,11 \%$ & $17,63 \%$ \\
\hline$B C I$ & $0,21 \%$ & $5,05 \%$ & $4,25 \%$ & $-0,09 \%$ & $1,35 \%$ & $-6,70 \%$ \\
\hline$S \& P G S C I$ & $0,17 \%$ & $7,00 \%$ & $2,48 \%$ & $-0,14 \%$ & $3,07 \%$ & $-4,62 \%$ \\
\hline Benchmark & $0,25 \%$ & $5,21 \%$ & $4,75 \%$ & l & l & l \\
\hline
\end{tabular}

Note: Risk and return characteristics are according to Amenc et al. (2009) and Amenc et al. (2010)

${ }^{a}$ Calculated as the average of the five existing indices

${ }^{\mathrm{b}}$ Calculated as average monthly return / standard deviation of monthly returns

${ }^{c}$ Calculated as average monthly excess return over the benchmark excluding the current index

${ }^{\mathrm{d}}$ Calculated as standard deviation of the monthly excess return over the benchmark excluding the current index

${ }^{\mathrm{e}}$ Calculated as active return / tracking error

As it could already be seen in the graph above, the MCCI from an overall view has by far the highest average monthly return, but also a higher risk in terms of standard deviation. Regarding the Sharpe-ratio, which is according to the capital market theory the most crucial criterion for investment performance, the overview indicates that the MCCI shows the highest value compared to existing commodity indices. Hence, even if there is potentially higher risk, due to a high share of the energy section in the MCCI, it shows a better performance than other representatives in relation to accepted risk. A further important performance indicator is the information ratio. We can see that the MCCI has a relatively high and positive information ratio of $7.32 \%$. The RICI is the only index offering a higher information ration, which is mostly due to the significantly lower tracking error.

As an additional test of the historical performance, we further calculate the performance indicators within each year of the data set and compare the yearly performance of the MCCI to the existing commodity indices and to prove statistical significance. Based on these calculations we first perform a t-test on the mean differences with Newey-West adjustment using a lag length of 1 . The results for this analysis are presented in Table 8. Secondly, we perform a Wilcoxon test on the differences in yearly medians, which are presented in Table 9. 
Table 8. Performance characteristics - risk and return on a yearly basis

\begin{tabular}{ccccccc}
\hline Index & $\begin{array}{c}\text { Monthly } \\
\text { average } \\
\text { return }\end{array}$ & $\begin{array}{c}\text { monthly } \\
\text { standard } \\
\text { deviation }\end{array}$ & $\begin{array}{c}\text { Sharpe- } \\
\text { ratio }\end{array}$ & $\begin{array}{c}\text { excess } \\
\text { return }\end{array}$ & $\begin{array}{c}\text { tracking } \\
\text { error }^{\mathrm{d}}\end{array}$ & $\begin{array}{c}\text { information } \\
\text { ratio }^{\mathrm{e}}\end{array}$ \\
\hline RJ/CRB & $0,24 \%$ & $1,93 \% * * *$ & $0,07 \%$ & $0,24 \% *$ & $3,7 \% * * *$ & $-8,6 \% * *$ \\
$C C I$ & $0,38 \%$ & $2,92 \% * * *$ & $0,56 \%$ & $0,39 \%$ & $1,6 \% * * *$ & $10,3 \%$ \\
$R I C I$ & $0,17 \%$ & $1,55 \% * * *$ & $-0,73 \%$ & $0,13 \% *$ & $3,2 \% * * *$ & $-9,8 \% * *$ \\
$B C I$ & $0,39 \%$ & $2,13 \% * * *$ & $5,15 \%$ & $0,41 \%$ & $2,9 \% * * *$ & $18,5 \%$ \\
$S \& P G S C I$ & $0,44 \%$ & $0,21 \% * * *$ & $7,69 \%$ & $0,47 \%$ & $1,3 \% * * *$ & $14,9 \%$ \\
\hline
\end{tabular}

${ }^{a}$ All numbers calculated as the mean of yearly differences between the MCCI and the corresponding index

$\mathrm{b} *$ represents $\mathrm{p}$-values $<0.1$, ** represents $\mathrm{p}$-values $<0.05, * * *$ represents $\mathrm{p}$-values $<0.01$ for a t-test using Newey-West adjustment and a lag length of 1 .

Table 9. Performance characteristics - risk and return on a yearly basis

\begin{tabular}{|c|c|c|c|c|c|c|}
\hline Index $^{a}$ & $\begin{array}{c}\text { Monthly } \\
\text { average } \\
\text { return }\end{array}$ & $\begin{array}{l}\text { monthly } \\
\text { standard } \\
\text { deviation }\end{array}$ & $\begin{array}{l}\text { Sharpe- } \\
\text { ratio }^{b}\end{array}$ & $\begin{array}{l}\text { excess } \\
\text { return }^{c}\end{array}$ & $\begin{array}{l}\text { tracking } \\
\text { error }^{\mathrm{d}}\end{array}$ & $\begin{array}{l}\text { information } \\
\text { ratio }^{\mathrm{e}}\end{array}$ \\
\hline$R J / C R B$ & $0,41 \%$ & $2,04 \%$ *** & $2,98 \%$ & $0,26 \%$ & $3,4 \%{ }^{* * *}$ & $-7,7 \%$ \\
\hline$C C I$ & $0,10 \%$ & $3,11 \%{ }^{* * *}$ & $-11,23 \%$ & $0,67 \%$ & $1,6 \%{ }^{* * *}$ & $17,9 \%$ \\
\hline RICI & $0,07 \%$ & $1,72 \%$ *** & $-0,86 \%$ & $0,06 \%$ & $3,0 \%{ }^{* * *}$ & $-23,2 \%$ \\
\hline$B C I$ & $0,55 \%$ & $2,06 \%$ & $3,92 \%$ & $0,43 \%$ & $2,8 \%^{* * *}$ & $15,5 \%$ \\
\hline$S \& P G S C I$ & $0,42 \%{ }^{*}$ & $0,13 \%$ & $7,10 \%$ & $0,23 \%{ }^{*}$ & $1,4 \%^{* * *}$ & $6,2 \%$ \\
\hline
\end{tabular}

${ }^{\mathrm{a}}$ All numbers calculated as the median of yearly differences between the MCCI and the corresponding index

$\mathrm{b}^{*}$ represents p-values $<0.1, * *$ represents p-values $<0.05, * * *$ represents $\mathrm{p}$-values $<0.01$ for a wilcoxon test

From these two analyses one can see that due to the high standard deviations of the MCCI returns, the differences in the average return and excess return are positive, but mostly not significant. Accordingly, the standard deviations of the returns and excess returns of the MCCI are significantly higher. Nevertheless, due to its return characteristics the Sharpe-Sharpe ratio is still high compared to the other existing indices. Consequently, the information ratio of the MCCI on a $10 \%$ level is significantly lower compared to the CRB and the RICI.

Overall, one can see that the MCCI offers very attractive risk-return-characteristics compared to existing commodity indices. Therefore, it could be interesting for practitioners to follow this approach and launch a commodity index based on market capitalization and thereby address the increasing demand for passive investment possibilities via index funds.

\section{Robustness checks}

Because of the strongly limited data availability in some cases, a number of assumptions and approximations concerning several parameters of the valuation approach are necessary. In order to check the sensitivity of the results in relation to these parameters, we perform several checks and scenario analyses, described in the following. 
As data availability for recycling costs of metals in particular is quite poor, they are approximated as described before. In order to test the sensitivity of our results in relation to this assumption, we recalculate index weightings using a recycling cost of $50 \%$ of respective cash costs for the commodity, with the highest market value (gold) and the lowest market value (aluminium), keeping all other parameters constant. This scenario analysis also shows that index weights do not differ significantly (see also Table 10 and Figure 3 in the appendix). Resulting differences are rather negligible, amounting to merely $0.11 \%$. Therefore, our results are robust even when our approximation for recycling costs should be inexact for specific commodities.

Table 10. Scenario 1 (Change in recycling costs)

\begin{tabular}{cccccc}
\hline Commodity & $\begin{array}{c}\text { Original MV (bn } \\
\text { USD) }\end{array}$ & Original share & $\begin{array}{c}\text { MV Scenario 1 } \\
\text { (bn USD) }\end{array}$ & $\begin{array}{c}\text { Share } \\
\text { Scenario 1 }\end{array}$ & Difference \\
\hline Crude Oil & 79,753 & $29.20 \%$ & 79.753 & $29,16 \%$ & $-0,04 \%$ \\
Natural gas & 801 & $0.29 \%$ & 801 & $0,29 \%$ & $0,00 \%$ \\
Heating Oil & 27,827 & $10.19 \%$ & 27.827 & $10,17 \%$ & $-0,02 \%$ \\
Gasoline & 54,003 & $19.77 \%$ & 54.003 & $19,74 \%$ & $-0,03 \%$ \\
Gas Oil & 40,843 & $14.96 \%$ & 40.843 & $14,93 \%$ & $-0,03 \%$ \\
Aluminium & 387 & $0.14 \%$ & 471 & $0,17 \%$ & $0,03 \%$ \\
Gold & 30,014 & $10.99 \%$ & 30.366 & $11,10 \%$ & $0,11 \%$ \\
Copper & 25,671 & $9.40 \%$ & 25.671 & $9,39 \%$ & $-0,01 \%$ \\
Nickel & 6,136 & $2.25 \%$ & 6.136 & $2,24 \%$ & $-0,01 \%$ \\
Silver & 1,694 & $0.62 \%$ & 1.694 & $0,62 \%$ & $0,00 \%$ \\
Zinc & 458 & $0.17 \%$ & 458 & $0,17 \%$ & $0,00 \%$ \\
Grain & 850 & $0.31 \%$ & 850 & $0,31 \%$ & $0,00 \%$ \\
Cattle & 1,769 & $0.65 \%$ & 1.769 & $0,65 \%$ & $0,00 \%$ \\
Soft/Agricl. & 2,889 & $1.06 \%$ & 2.889 & $1,06 \%$ & $0,00 \%$ \\
\hline
\end{tabular}

Table 11. Scenario 2 (discount rate $+2,5 \%$ )

\begin{tabular}{cccccc}
\hline Commodity & $\begin{array}{c}\text { Original MV (bn } \\
\text { USD) }\end{array}$ & Original share & $\begin{array}{c}\text { MV Scenario 2 } \\
\text { (bn USD) }\end{array}$ & $\begin{array}{c}\text { Share } \\
\text { Scenario 2 }\end{array}$ & Difference \\
\hline Crude Oil & 79,753 & $29.20 \%$ & 39,848 & $23.33 \%$ & $-5.87 \%$ \\
Natural gas & 801 & $0.29 \%$ & 153 & $0.09 \%$ & $-0.20 \%$ \\
Heating Oil & 27,827 & $10.19 \%$ & 13,818 & $8.09 \%$ & $-2.10 \%$ \\
Gasoline & 54,003 & $19.77 \%$ & 26,816 & $15.70 \%$ & $-4.07 \%$ \\
Gas Oil & 40,843 & $14.96 \%$ & 20,281 & $11.88 \%$ & $-3.08 \%$ \\
Aluminium & 387 & $0.14 \%$ & 387 & $0.23 \%$ & $0.09 \%$ \\
Gold & 30,014 & $10.99 \%$ & 30,014 & $17.57 \%$ & $6.58 \%$ \\
Copper & 25,671 & $9.40 \%$ & 25,671 & $15.03 \%$ & $5.63 \%$ \\
Nickel & 6,136 & $2.25 \%$ & 6,136 & $3.59 \%$ & $1.34 \%$ \\
Silver & 1,694 & $0.62 \%$ & 1,694 & $0.99 \%$ & $0.37 \%$ \\
Zinc & 458 & $0.17 \%$ & 458 & $0.27 \%$ & $0.10 \%$ \\
Grain & 850 & $0.31 \%$ & 850 & $0.50 \%$ & $0.19 \%$ \\
Cattle & 1,769 & $0.65 \%$ & 1,769 & $1.04 \%$ & $0.39 \%$ \\
Soft/Agricl. & 2,889 & $1.06 \%$ & 2,889 & $1.69 \%$ & $0.63 \%$ \\
\hline
\end{tabular}


Another robustness check addresses the sensitivity of the approach in relation to discount rates. First, the energy sector, representing the largest group within the MCCI, is re-estimated using a $2.5 \%$ higher discount rate (scenario: $M V \_h i g h \_p l u s \_2.5 \%$ ). Secondly, the group with the lowest index share (grains) is recalculated using a $2.5 \%$ lower discount rate (scenario: $M V \_l o w \_m i n u s \_2.5 \%$ ), ceteris paribus. Although the change of $+2.5 \%$ in discount rate for the energy sector is quite high, the index weightings only change to a minor extent (see also Table 9 and Figure 3). The weight of crude oil decreases from $29.20 \%$ to $23.33 \%$, but still remains the dominant constituent in the MCCI. Weights for gold and copper increase by $6.58 \%$ and $5.63 \%$; consequently, they are marginally more important than derivatives of oil. In the third scenario, the discount rate for grains decreases by $2.5 \%$, having only a very small impact on the weightings (see also Table 10 and Figure 3).

Table 12. Scenario 3 (discount rate $\mathbf{- 2 , 5 \%}$ )

\begin{tabular}{cccccc}
\hline Commodity & $\begin{array}{c}\text { Original MV (bn } \\
\text { USD) }\end{array}$ & Original Share & $\begin{array}{c}\text { MV Scenario 3 } \\
\text { (bn USD) }\end{array}$ & $\begin{array}{c}\text { Share } \\
\text { Scenario 3 }\end{array}$ & Difference \\
\hline Crude Oil & 79,753 & $29.20 \%$ & 79,753 & $29.19 \%$ & $-0.01 \%$ \\
Natural gas & 801 & $0.29 \%$ & 801 & $0.29 \%$ & $0.00 \%$ \\
Heating Oil & 27,827 & $10.19 \%$ & 27,827 & $10.18 \%$ & $-0.01 \%$ \\
Gasoline & 54,003 & $19.77 \%$ & 54,003 & $19.76 \%$ & $-0.01 \%$ \\
Gas Oil & 40,843 & $14.96 \%$ & 40,843 & $14.95 \%$ & $-0.01 \%$ \\
Aluminium & 387 & $0.14 \%$ & 387 & $0.14 \%$ & $0.00 \%$ \\
Gold & 30,014 & $10.99 \%$ & 30,014 & $10.98 \%$ & $-0.01 \%$ \\
Copper & 25,671 & $9.40 \%$ & 25,671 & $9.40 \%$ & $0.00 \%$ \\
Nickel & 6,136 & $2.25 \%$ & 6,136 & $2.25 \%$ & $0.00 \%$ \\
Silver & 1,694 & $0.62 \%$ & 1,694 & $0.62 \%$ & $0.00 \%$ \\
Zinc & 458 & $0.17 \%$ & 458 & $0.17 \%$ & $0.00 \%$ \\
Grain & 850 & $0.31 \%$ & 994 & $0.36 \%$ & $0.05 \%$ \\
Cattle & 1,769 & $0.65 \%$ & 1,769 & $0.65 \%$ & $0.00 \%$ \\
Soft/Agricl. & 2,889 & $1.06 \%$ & 2,889 & $1.06 \%$ & $0.00 \%$ \\
\hline
\end{tabular}

A third back-testing activity concerning the extrapolation of future commodity prices is performed. To determine the future price path, we apply the well-known Hotelling model (Hotelling 1931). However, this model is designed only for non-renewable resources. Due to the monopolistic market structure of many commodities, a monopoly situation is assumed while calculating the model. Based on the results of the robustness check for oil and metals, the average rate of return forecast is valid, as the index weightings using the Hotelling model do not differ significantly and therefore the overall picture of the index composition does not change.

In summary, these robustness checks concerning the most important parameters of the valuation model show that the necessary assumptions and approximations do not have a significant influence on the index weightings. In other words, the presented index weighting can be seen as reliable representatives for a truly market cap weighted commodity index. 


\section{Figure 3. Scenario analysis}

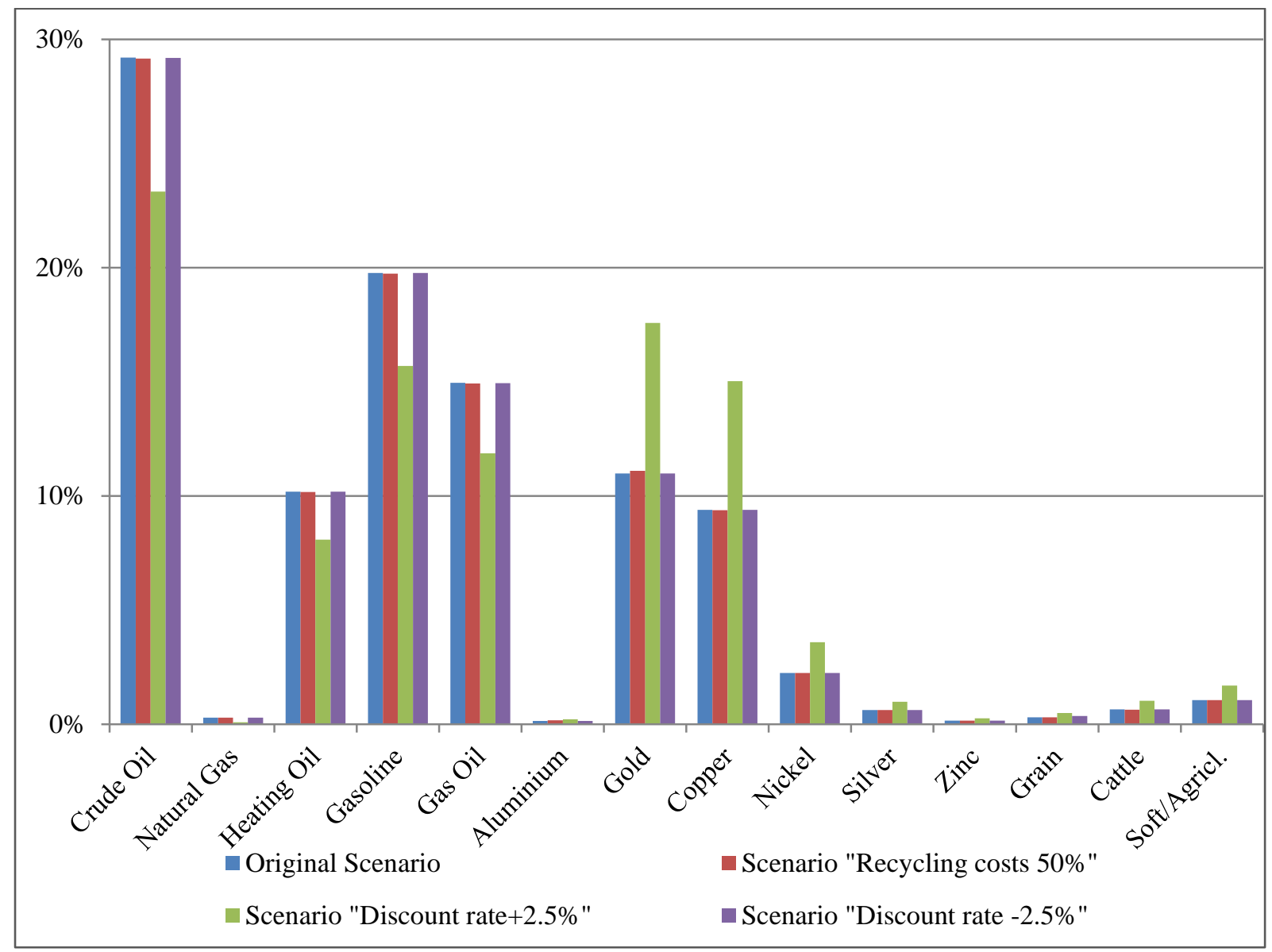

${ }^{a}$ Note: For the first scenario, the recycling cost of gold that displays the commodity with the highest market value, and of aluminium, being the material with the lowest market value, is defined to be as high as $50 \%$ of the cash costs. All other metals, energy commodities, and factors remain static.

'In the second scenario, the discount rate is recalculated by adding $+2.5 \%$ to the discount rate defined beforehand for the commodities with the highest market value (energy sector).

${ }^{c}$ Within the third scenario, the discount rate is recalculated by subtracting $-2.5 \%$ of the discount rate defined beforehand for the commodities with the lowest market value (grains).

\section{Conclusion}

This paper presents an indexation approach for commodities, based on the theoretical CAPM framework, which according to Broby (2007) is the best way to diversify unsystematic risk leading to an unbiased relation between systematic risk and return. Due to the difficulty and complexity of determining the market capitalization of commodities, existing commodity indices use other fundamental properties, such as liquidity or world production, as weighting criterions.

By using a discounted cash-flow approach, we are the first to determine and assess the total market value of the overall stock of a commodity. Thus, in line with classical capital market theory, we enable a capitalization weighted commodity indexation, offering a variety of benefits compared to existing commodity indices. Constituents are weighted based on the objective criterion of the market capitalization. Since this approach represents the common and established practice for stocks, commodity index weightings derived by the presented approach are more comparable to their respective stock market equivalents. Furthermore, they are not driven by subjective goals or arbitrariness of index publishing 
institutions. As the approach is not only restricted to the price perspective, but includes cash costs, recycling costs, investment costs, and future demand, it can be interpreted as an innovative and representative approach of commodity index construction.

Results from the example application of the presented approach demonstrate that aluminium, silver, natural gas, and the majority of soft commodities are overvalued, whereas oil and its derivatives are significantly underrepresented in existing indices. Furthermore, evaluation and robustness checks confirm reliability of the market capitalization based commodity index construction. Regarding the Sharperatio, which according to the efficient market theory is the most suitable performance measure the MCCI offers attractive risk-return-characteristics in the long-term outperform existing index compilations. In detail the MCCI achieved an average monthly return of $0.61 \%$ and a Sharpe-ratio of $8.38 \%$. The Rogers Index, which is the best among existing indices only achieves a monthly return of $0.44 \%$ and a Sharpe ratio of $7.83 \%$.

This finding has important implications for both, scientists and practitioners. For practitioners it could be interesting to follow this approach and launch a commodity index based on market-capitalization and thereby address the increasing demand for indirect investment possibilities via index funds.

Further, this paper can contribute to the extensive scientific debate concerning index construction and weighting schemes. Our results support the capital market theory and thereby the market cap weighting, as the MCCI can outperform other indices following different weighting criterions, such as equal weighting and different fundamental weighting schemes.

However, regarding its practical application, there are several implications of the present concept, which have to be further assessed. For instance, turnover as well as rebalancing issues have to be considered when implementing this approach as an investment product. Furthermore, as with all assessments, a reliable data basis for estimates of future prices and demands is crucial. Therefore, the comprehensive implementation of the presented indexation methodology is an important challenge for future research and practice.

All in all, we are confident that our approach, based on the fundamentals of the capital market theory, can contribute to a more substantive view on commodity indexation. 


\section{References}

Amenc, N., Goltz, F. and Le Sourd, V. (2006) Assessing the Quality of Stock Market Indices. EDHEC Risk \& Asset Management Research Centre Publication.

Amenc, N., Goltz, F. and Le Sourd, V. (2009) The Performance of characteristics-based indices. European Financial Management 15(2): 241-278.

Amenc, N., Goltz, F., Martellini, L. and Retkowsky, P. (2010) Efficient Indexation: An Alternative to Cap-Weighted Indices. EDHEC-Risk Institute Publication.

Arnott, R. D., Hsu, J. C. and Moore, P. (2005) Fundamental Indexation. The Financial Analysts Journal 60(2): 83-99.

Arnott, R. D., Kalesnik, V., Moghtader, P. and Scholl, C. (2010) Beyond Cap-Weight: The Search for Efficient Beta. Journal of Indexes (January-February): 16-29.

Basu, A. K., Forbes, B. (2014) Does Fundamental Indexation lead to better risk-adjusted Returns? New Evidence from Australian Securities Exchange. Accounting and Finance 54(3): 699-728.

Broby, D. (2007) A Guide to Equity Index Construction. Risk books, London.

Broby, D. (2011) Equity Index Construction. The Journal of Index Investing 2(2): 36-39.

Cochrane, J. H. (2011) Presidential Address: Discount Rates. The Journal of Finance 66(4): 1540-6261.

Damodaran, A. (2001) Corporate Finance: Theory and Practice. John Wiley \& Sons, Inc., Hoboken, NJ, USA.

Doyle, E., Hill, J., and Jack, I. (2007) Growth in Commodity Investment: Risks and Challenges for Commodity Market Participants. Financial Services Authority.

Fabozzi, F., Füss, R. and Kaiser, D. G. (2008) The Handbook of Commodity Investing. John Wiley \& Sons, Inc., Hoboken, NJ, USA.

Fama, E. F., French, K. R. (1997) Industry costs of equity. Journal of Financial Economics 43(2): 153193.

FAOSTAT (2015) Methods \& Standards. URL: http://faostat3.fao.org/mes/glossary/E, accessed on 08.08.2015, 13:00.

Fisher, G. S., Shah, R., Titman, S. (2015) Decomposing Fundamental Indexation. Working Paper.

Goldman Sachs (2015) S\&P GSCI Commodity Index Approach. URL: http://www.goldmansachs.com/what-we-do/securities/products-and-business-groups/products/gsci/approach.html, accessed on: 15.06.2015, 14:15.

Gorton, G. and Rouwenhorst, G. (2006) Facts and Fantasies about Commodity Futures. The Financial Analysts Journal 62(2): 47-68.

Greer, R. J. (2000) The Nature of Commodity Index Returns. The Journal of Alternative Investments 3(1): 45-52.

Grinold, R. (1992) Are benchmark portfolios efficient? Journal of Portfolio Management 19(1): 34-40. 
Hartwick, J. M. (1977) Intergenerational Equity and the Investing of Rents from Exhaustible Resources. The American Economic Review 67(5): 972-974.

Haugen, R. and Baker, N. (1991) The efficient market inefficiency of capitalization-weighted stock portfolios. Journal of Portfolio Management 17(3): 35-40.

Hotelling, H. (1931) The Economics of Exhaustible Resources. Journal of Political Economy 39(2): $137-175$.

Hsu, J. C. (2006) Cap-Weighted Portfolios Are Sub-Optimal Portfolios. Journal of Investment Management 4(3): 1-10.

Lide, D. R. (ed.) (2005) CRC Handbook of Chemistry and Physics, Section 14, Geophysics, Astronomy, and Acoustics; Abundance of Elements in the Earth's Crust and in the Sea. CRC Press, Boca Raton.

Lintner, J. (1965) Security Prices, Risk and Maximal Gains from Diversification. The Journal of Finance 20(4): 587-615.

McKelvey, V. E. (1974). Potential mineral reserves. Resources Policy 1(2): 75-81.

Metal Radar (2013) London Metal Exchange - History and Prices of LME Copper. URL: http://www.metalradar.com/copper-lme, accessed on: 26.11.2013, 09:53.

Perold, A. F. (2007) Fundamentally Flawed Indexing. The Financial Analysts Journal 63(6): 31-37.

Rogers (2015) THE RICI. URL: http://www.rogersrawmaterials.com/home.asp, accessed on: 15.06.2015, 12:50.

Rosenau-Tornow, D., Buchholz, P., Riemann, A. and Wagner, M. (2009) Assessing the long-term supply risks for mineral raw materials - a combined evaluation of past and future trends. Resources Policy 34(4): 161-175.

Sharpe, W. F. (1964) Capital Asset Prices: A Theory of Market Equilibrium under Conditions of Risk. The Journal of Finance 19(3): 425-442.

Sharpe, W. F. (1965) Risk-Aversion in the Stock Market: Some Empirical Evidence. The Journal of Finance 20(3): 416-422.

Slade, M. E. (1982) Trends in natural-resource commodity prices: an analysis of the time domain. Journal of Environmental Economics and Management 9(2): 122-137

Solow, R. M. (1974) The Economics of Resources or the Resources of Economics. The American Economic Review 64(2): 1-14.

Southard J. and Bond, B. (2003) Intelligent Indices - The Scientific Approach to Money Management. Journal of Indices (Fourth Quarter).

Thomson Reuters (2013) Corecommodity CRB Index Calculation Supplement. URL: thomsonreuters.com/content/.../rulebook-crb-2013-08-22.pdf. 


\section{Appendix A. Data sources}

In Table A1, we report the sources for data used for calculations in the valuation approach.

Table A1. Input data sources

\begin{tabular}{|c|c|}
\hline Data & Sources \\
\hline \multirow[t]{3}{*}{ Resources } & $\begin{array}{l}\text { BGR. 2013. "Energiestudie 2013. Reserven, Ressourcen und Verfügbarkeit von Energierohstoffen." No. 17, } \\
\text { Hannover. }\end{array}$ \\
\hline & $\begin{array}{l}\text { USGS. 2013a. "Mineral Commodity Summaries 2013." URL: http://minerals.usgs.gov/miner- } \\
\text { als/pubs/mcs/2013/mcs2013.pdf, accessed on: } 20.08 .2013,18: 00 .\end{array}$ \\
\hline & $\begin{array}{l}\text { Lide, David R. 2005. "CRC Handbook of Chemistry and Physics, Section 14, Geophysics, Astronomy, and } \\
\text { Acoustics; Abundance of Elements in the Earth's Crust and in the Sea." CRC Press, Boca Raton. }\end{array}$ \\
\hline $\begin{array}{l}\text { Commodity } \\
\text { prices }\end{array}$ & Thomson Reuters Datastream, accessed 25.08.2013. \\
\hline $\begin{array}{l}\text { Slope } \\
\text { Hotelling }\end{array}$ & $\begin{array}{l}\text { BP. 2013. "Statistical Review of World Energy 2013. Historical Data Workbook." URL: } \\
\text { http://www.bp.com/en/global/corporate/about-bp/energy-economics/statistical-review-of-world-energy- } \\
\text { 2013.html, accessed on: } 20.08 .2013,18: 30 \text {. }\end{array}$ \\
\hline
\end{tabular}

Thomson Reuters Datastream, accessed 25.08.2013.

USGS. 2013b. "Historical Statistics for Mineral and Material Commodities in the United States.", URL: http://minerals.usgs.gov/ds/2005/140/, accessed on: 20.08.2013, 18:20.

Investment Ericsson, Magnus, and Viktoriya Larsson. 2013. "E\&MJ's Annual Survey of Global Mining Investment." costs Engineering and Mining Journal, URL: http://www.e-mj.com/index.php/features/2541-e-mj-s-annual-survey-of-global-mining-investment, accessed on: 14.08.2013, 09:15.

Karl, Hans-Dieter. 2010. “Abschätzung der Förderkosten für Energierohstoffe.” Ifo Schnelldienst, vol.63, no. 2:21-29.

Cash Costs Dorner, Ulrike. 2013. "DERA Rohstoffinformationen, Rohstoffrisikobewertung - Kupfer." Schriftenreihe in $\mathrm{t}_{0}$ DERA Rohstoffinformationen, no. 16, URL: http://www.bgr.bund.de/DERA/DE/Rohstoffinformationen/Schriftenreihe/schriftenreihe_node.html, accessed on: 14.08.2013, 09:00.

Evrell, Lennart, and Jan Moström. 2011. "Expansion Garpenberg.” URL: http://www.boliden.com/Documents/Press/Presentations/Garpenberg-expansion_svensk.pdf, accessed on: 14.08.2013, 09:27.

Karl, Hans-Dieter. 2010. “Abschätzung der Förderkosten für Energierohstoffe.” Ifo Schnelldienst, vol.63, no. 2:21-29.

Mitchell, Andrew, and Sean Mulshaw. 2009. "Nickel Industry Production Costs: Implications for Project Development and Nickel Prices." Wood Mackenzie, URL: http://www.insg.org/presents/Mr_Mitchell_Apr09.pdf, accessed on: 19.08.2013, 18:00.

Noranda Aluminium Holding Corporation. 2012. "Jefferies Global Industrial Conference.” URL: http://investor.norandaaluminum.com/phoenix.zhtml?c=220051\&p=irol-presentations, accessed on: 09.09.2013, $14: 20$.

N.U. 2013. "SILVER COSTS: Much Higher Than Most Realize." URL: http://srsroccoreport.com/silvercosts-much-higher-than-most-realize/silver-costs-much-higher-than-most-realize/, accessed on: 20.08.2013, $18: 35$.

Reeve, Firman. 2011. “ABN AMRO Gold Mine Cost Report Q1 2011 - VM Group/Haliburton commodity research - June 2011.” URL: http://www.virtualmetals.co.uk/pdf/ABNGCQ111.pdf, accessed on: 14.08.2013, 09:23.

Reuters. 2009. "FACTBOX-Oil Production Cost Estimates by Country." URL: http://www.reuters.com/article/2009/07/28/oil-cost-factbox-idUSLS12407420090728, accessed on: 14.08.2013, 09:20. 


\begin{tabular}{|c|c|}
\hline $\begin{array}{l}\text { Recycling } \\
\text { rate }\end{array}$ & $\begin{array}{l}\text { USGS. 2013a. "Mineral Commodity Summaries 2013." } \\
\text { als/pubs/mcs/2013/mcs2013.pdf, accessed on: } 20.08 .2013 \text {, 18:00. }\end{array}$ \\
\hline \multirow{2}{*}{$\begin{array}{l}\text { Discount } \\
\text { rate }\end{array}$} & Thomson Reuters Datastream, accessed 25.08.2013. \\
\hline & $\begin{array}{l}\text { MSCI ACWI Select Agriculture Producers Investable Market Index, URL: https://www.msci.com/re- } \\
\text { sources/factsheets/MSCI_ACWI_Select_Agriculture_Producers_IMI.pdf }\end{array}$ \\
\hline $\begin{array}{l}\text { Risk-free } \\
\text { rate }\end{array}$ & $\begin{array}{l}\text { Bloomberg. 2013. "United States Government Bonds - Bloomberg." URL: www.bloomberg.com/mar- } \\
\text { kets/rates-bonds/government-bonds/us/, accessed on: 14.08.2013, 09:25. }\end{array}$ \\
\hline $\begin{array}{l}\text { Inflation } \\
\text { rate }\end{array}$ & $\begin{array}{l}\text { Global-Rates. 2013. "VPI Inflation - Übersicht über aktuelle international Inflationsraten - Verbraucher- } \\
\text { preisindex." URL :http://de.global-rates.com/wirtschaftsstatistiken/inflation/verbraucher- } \\
\text { preisen/vpi/vpi.aspx, accessed on: 14.08.2013, 09:21. }\end{array}$ \\
\hline $\begin{array}{l}\text { Recycling } \\
\text { costs }\end{array}$ & $\begin{array}{l}\text { Benefits of Recycling. 2013. “Copper Recycling Prices.“ URL: http://www.benefits-of-recycling.com/cop- } \\
\text { perrecyclingprices/, accessed on: 01.08.2013, 09:03. }\end{array}$ \\
\hline \multirow[t]{5}{*}{$\begin{array}{l}\text { Demand } \\
\text { forecasts }\end{array}$} & $\begin{array}{l}\text { Angerer, Gerhard, Frank Marscheider-Weidemann, Lorenz Erdmann, Michael Scharp, Arne Lüllmann, Vol- } \\
\text { ker Handke, and Max Marwerde. 2009. "Rohstoffe für Zukunftstechnologien, Einfluss des branchenspezifi- } \\
\text { schen Rohstoffbedarfs in rohstoffintensiven Zukunftstechnologien auf die zukünftige Rohstoffnach- } \\
\text { frage." Fraunhofer IRB Verlag, Karlsruhe. }\end{array}$ \\
\hline & $\begin{array}{l}\text { Angerer, Gerhard, Frank Marscheider-Weidemann, Alexandra Mohring, and Martin Wietschel. 2010. "Kup- } \\
\text { fer für Zukunftstechnologien - Nachfrage und Angebot unter besonderer Berücksichtigung der Elektromo- } \\
\text { bilität." Fraunhofer ISI, Karlsruhe. }\end{array}$ \\
\hline & $\begin{array}{l}\text { IEA. 2009. "World Energy Outlook 2009.“ URL:http://www.worldenergyoutlook.org/media/weoweb- } \\
\text { site/2009/WEO2009.pdf, accessed on: 20.08.2013, 18:35. }\end{array}$ \\
\hline & $\begin{array}{l}\text { IndexMundi (2014): "Production per year", URL:http://www.indexmundi.com/energy.aspx?product=bio- } \\
\text { diesel\&graph=production, accessed on: 06.02.2013, 18:35. }\end{array}$ \\
\hline & RWO Essen, Fraunhofer ISI and BGR. 2010. "Copper Foresight."Fraunhofer ISI, Karlsruhe. \\
\hline \multirow[t]{4}{*}{$\begin{array}{l}\text { Index } \\
\text { weightings }\end{array}$} & $\begin{array}{l}\text { New York Board of Trade. 2013. "CCI - Continuous Commodity Index - Futures \& Options." URL: } \\
\text { http://www.gofutures.com/pdfs/Continuous-Commodity-Index.pdf, accessed on: 08.09.2013, 15:25. }\end{array}$ \\
\hline & $\begin{array}{l}\text { Reuters. 2012. "Top Commodity Index S\&P GSCI Hikes WTI Weight, Cuts Brent for 2013." URL: } \\
\text { http://www.reuters.com/article/2012/11/05/commodity-index-gsci-idAFL1E8M5EWD20121105, accessed } \\
\text { on: } 21.08 .2013,18: 40 \text {. }\end{array}$ \\
\hline & $\begin{array}{l}\text { Rogers. 2013. "The RICI Weighting." URL: http://www.rogersrawmaterials.com/weight.asp, accessed on: } \\
\text { 22.08.2013, 12:50. }\end{array}$ \\
\hline & $\begin{array}{l}\text { S\&P Dow Jones Indices. 2013. "2013 Weights for the Dow Jones-UBS Commodity Index Announced by } \\
\text { S\&P Dow Jones Indices and UBS Investment Bank." URL: http://press.djindexes.com/index.php/2013- } \\
\text { weights-for-the-dow-jones-ubs-commodity-index-announced-by-sp-dow-jones-indices-and-ubs-invest- } \\
\text { ment-bank/, accessed on: } 27.08 .2013,10: 38 \text {. }\end{array}$ \\
\hline Production & United States Department of Agriculture Economic Research Service (USDA ERS) \\
\hline Values for & http://www.ers.usda.gov/data-products/commodity-costs-and-returns.aspx \\
\hline $\begin{array}{l}\text { non-renewa- } \\
\text { ble Com- } \\
\text { modities }\end{array}$ & $\begin{array}{l}\text { Food And Agriculture Organization of the United Nations Statistics Division (FAOSTAT) } \\
\text { http://faostat3.fao.org/download/P/PP/E }\end{array}$ \\
\hline
\end{tabular}

